\title{
Penggunaan Metode Cooperative Integrated Reading and Composotion (CIRC) Dalam Pembelajaran Bahasa Indonesia Untuk Meningkatkan Kemampuan Membaca Siswa Pada Kelas IV MI Mambaul Huda Ngabar Ponorogo
}

\author{
Oleh: Iis Uun Fardiana
}

\begin{abstract}
In the course of learning, the use of a particular method of learning is very influential on learning outcomes to be achieved. But in reality, the Indonesian learning process at the school is still using methods tend menoton explained in front of the class were students just listen to information from the teacher, so that the learning process is not conducive and effective learning process difficult to achieve.

This study focused on (1) whether the method of Cooperative Integrated Reading and Composition (CIRC) can improve students' reading ability? (2) how to use the methods Cooperative Integrated Reading and Composition (CIRC) can improve students' reading ability? The goal was to determine the use of methods Cooperative Integrated Reading and Composition (CIRC) can increase the ability to read student, knowing how teachers use methods Cooperative Integrated Reading and Composition (CIRC) to increase the ability to read students learning Indonesian in MI Mamba'ul Huda Ngabar Ponorogo.
\end{abstract}

Desaian research is classroom action research (classroom action research) and the type of research is collaborative with teachers and pupils. The results showed that, using the method of Cooperative Integrated Reading and Composition (CIRC) can improve the reading skills of students learning Indonesian in MI Mamba'ul Huda Ngabar Ponorogo. It can be seen from the results of research that has been conducted by using the method of Cooperative Integrated Reading and Composition (CIRC) can improve reading ability siswadan active students in learning

Kata kunci: Method of Cooperative Integrated Reading and Composition (CIRC), learning Indonesian, Reading ability.

\section{PENDAHULUAN}

MI Mamba'ul Huda Ngabar Ponorogo merupakan lembaga pendidikan dasar di bawah naungan Departemen Agama. Sebagai salah satu lembaga pendidikan, MI Mamba'ul Huda Ngabar Ponorogo sangat menjunjung keberhasilan pembelajaran, sehingga siswa yang dihasilkan mampu berperan dalam persaingan global. Usaha 
kearah tersebut sudah banyak dilakukan oleh pihak madrasah terkait, seperti pemenuhan sarana prasarana, media pembelajaran, guru yang professional serta komponen lain yang mampu meningkatkan kualitas pendidikan. Namun di luar citacita luhur itu, MI Mamba'ul Huda Ngabar Ponorogo masih banyak mengalami permasalahan-permasalahan pembelajaran, khususnya dalam pembelajaran Bahasa Indonesia pada kelas IV yang menjadi objek kajian dalam penelitian ini. Masalahmasalah tersebut dapat diidentifikasi antara lain sebagai berikut :1) Rendahnya minat siswa untuk belajar Bahasa Indonesia sehingga siswa tidak terlalu memperhatikan pelajaran yang disampaikan guru. 2) Siswa menganggap remeh mata pelajaran Bahasa Indonesia karena dianggap sudah menjadi bahasa sehari-hari yang menurut mereka akan bisa dengan sendirinya. 3) Hasil belajar siswa yang masih rendah, baik dalam aspek berbicara, mendengarkan, menulis serta membaca dalam Bahasa Indonesia.

Jika dianalisa, permasalahan-permasalahan tersebut dapat disebabkan oleh beberapa hal, antara lain adalah:

a. Pelajaran Bahasa Indonesia yang kurang menarik

Di MI Mamba'ul Huda Ngabar Ponorogo, khususnya kelas IV, sebagian besar menganggap bahwa pelajaran Bahasa Indonesia tidak menarik buat mereka.Banyak hal yang mungkin menyebabkan siswa mempunyai persepsi seperti itu, seperti kurang menariknya guru menyampaikan pesan pembelajaran.Oleh karena itu, guru harus merubah semenarik mungkin dalam menyampaikan pelajaran, sehingga siswa juga mampu menyenangi pelajarannya.

b. Cara mengajar guru

Di MI Mamba'ul Huda Ngabar Ponorogo, pembelajaran Bahasa Indonesia oleh guru masih cenderung berorientasi pada transfer pengetahuan semata dengan metode yang monoton. Hal inilah yang mengakibatkan kegagalan prestasi belajar siswa. Selain itu, pembelajaran yang digunakan masih menganut perspektif pembelajaran tradisional, yaitu pembelajaran yang 
berpusat pada guru dan menjadikan siswa sebagai objek pasif yang harus banyak diisi informasi. Padahal kenyataannya, siswa yang mempunyai karakter beragam memerlukan sentuhan-sentuhan khusus dari guru sebagai pendidik dan pelatih agar mampu mengambil makna dari setiap informasi yang diterima. Untuk itu guru harus mampu menjadikan mereka semua terlibat dan merasa senang selama proses pembelajaran.

c. Media dan metode pembelajaran yang kurang inovatif

Sangat disadari bahwa ketersedian media di MI Mamba'ul Huda Ngabar Ponorogo memang sangat terbatas, hal itulah yang menjadi sebab melemahnya kemauan siswa untuk belajar Bahasa Indonesia, Karena dalam pembelajaran Bahasa Indonesia lebih banyak menekankan kepada keterampilan, baik dalam berbicara, mendengarkan, membaca dan menulis. Dengan demikian maka butuh kecerdasan dari seorang guru untuk memodifikasi suasana pembelajaran tanpa media yang lengkap. Selain itu, penggunaan metode yang tepat dan efektif juga akan membantu siswa mengalami keterbatasannya dalam menerima materi pelajaran Bahasa Indonesia.

Dari ketiga permasalahan yang ditemukan di atas, peneliti menfokuskan pembahasan pada permasalahan rendahnya minat belajar siswa khususnya minat membaca yang pada akhirnya mempengaruhi rendahnya hasil belajar siswa. Permasalahan ini di anggap penting untuk dibahas, karena ini merupakan salah satu permasalahan yang paling kompleks sekaligus merupakan dampak signifikan yang ditimbulkan dari permasalahan dianggap remehnya mata pelajaran Bahasa Indonesia selama ini.

Hilangnya minat belajar siswa sehingga mempengaruhi perolehan hasil belajar siswa yang rendah dengan ditandai perolehan skor nilai di bawah KKM yang telah ditentukan oleh sekolah. Hal ini disebabkan karena cara mengajar dari guru yang bersifat teacher centre atau pengajaran yang bersifat pada guru. Siswa tidak dapat 
mendapat kesempatan untuk mengeksplor potensi yang dimiliki, sehingga pembelajaran terkesan pasif dan kurang bergairah.

Salah satu alternatif yang dapat dilakukan oleh seorang guru guna menjawab dari permasalahan-permasalan pembelajaran Bahasa Indonesia tersebut, serta untuk lebih mengaktifkan dan meningkatkan kemampuan berbicara Bahasa Indonesia, yaitu dengan menggunakan metode CIRC. CIRC merupakan kepanjangan dari Cooperative Integrated Reading and Composotion, termasuk salah satu model pembelajaran Cooperative learning yang pada mulanya merupakan pengajaran kooperatif terpadu membaca dan menulis yaitu sebuah komprehensif atau luas dan lengkap untuk pengajaran membaca dan menulis untuk kelas-kelas tinggi sekolah dasar. Namun, CIRC telah berkembang bukan hanya dipakai pada pelajaran bahasa tetapi juga pada pelajaran eksak seperti pelajaran matematika.

Menurut pendapat Robert E. Slavin bahwa unsur-unsur yang terkandung dalam CIRC adalah meliputi: (1) kegiatan-kegiatan dasar terkait (2) pengajaran langsung pelajaran memahami bacaan dan seni berbahasa dan menulis terpadu. Dalam semua kegiatan ini siswa bekerja dalam tim-tim yang heterogen. Semua kegiatan mengikuti siklus regular yang melibatkan prestasi dari guru, latihan tim, latihan independen, pra penilaian teman, dan latihan tambahan. ${ }^{1}$

Dalam model pembelajaran CIRC, siswa ditempatkan dalam kelompokkelompok kecil yang heterogen, yang terdiri atas 4 atau 5 siswa. Dalam kelompok ini tidak dibedakan atas jenis kelamin, suku atau bangsa, atau tingkat kecerdasan siswa. Jadi dalam kelmpok ini sebaiknya ada siswa yang pandai, sedang atau lemah, dan masing-masing siswa merasa cocok satu sama lain. Dengan pembelajaran kooperatif, diharapkan para siswa dapat meningkatkan cara berfikir kritis, kreatif dan menumbuhkan rasa sosial yang tinggi.

\footnotetext{
${ }^{1}$ Amin Suyitno, Mengadopsi Pembelajaran CIRC dalam Meningkatkan Ketrampilan Siswa Menyelesaikan Soal Certia, (Seminar Nasional F. MIPA UNNES:2005)
} 


\section{PERMASALAHAN}

Sesuai dengan latar belakang yang telah dipaparkan, maka dapat dirumuskan masalah sebagai berikut:

Pertama, bagaimana penggunaan metode Cooperative Integrated Reading and Composition (CIRC) untuk meningkatkan kemampuan membaca siswa mata pelajaran Bahasa Indonesia kelas IV MI Mamba'ul Huda Ngabar Ponorogo?

Kedua, apakah penggunaan metode Cooperative Integrated Reading and Composition (CIRC) mampu meningkatkan kemampuan membaca siswa mata pelajaran Bahasa Indonesia kelas IV MI Mamba’ul Huda Ngabar Ponorogo?

\section{LANDASAN TEORI}

\section{Pembelajarn Kooperatif}

Cooperative learning berasal dari kata cooperative yang artinya mengerjakan sesuatu secara bersama-sama dengan saling membantu satu sama lainnya sebagai satu kelompok atau satu tim. ${ }^{2}$

\section{CIRC}

CIRC-Cooperatif Integrated And Composition merupakan metode kooperatif yang memperkenalkan teknik terbaru latihan kurikulum mengenai pengajaran praktis pelajaran membaca dan menulis. Pengembangan CIRC dihasilkan dari sebuah analisis masalah-masalah tradisional dalam pengajaran pelajaran membaca, menulis, dan seni berbahasa. ${ }^{3}$

\section{Peningkatan}

Berasal dari kata tingkat yang artinya jenjang, babak, mendapat imbuhan me-kan menjadi meningkatkan yang artinya membawa ke jenjang yang lebih tinggi atau membawa kejenjang berikutnya.

\footnotetext{
${ }^{2}$ Isjoni. Cooperative Learning Mengembangkan Kemampuan Belajarberkelompok. (Bandung: ALFABETA. 2009) hlm :15

${ }^{3}$ Robet E.Slavin. Cooperative Learning Teori, Riset dan Rraktik. (Bandung: Penerbit Nusa Media. 2008) hlm:200
} 


\section{Kemampuan Membaca}

Kemampuan seseorang untuk memperoleh pesan yang hendak disampaikan oleh penulis melalui media kata-kata/bahasa tulis. ${ }^{4}$

\section{Membaca intensif}

Merupakan kegiatan membaca bacaan secara kritis, teliti dan seksama dengan tujuan memperoleh keberhasilan dalam lpemahaman terhadap argument-argument yang terdapat dalam suatu teks bacaan.

\section{Bahasa Indonesia}

Merupakan bahasa resmi negara kesatuan Republik Indonesia. Bahasa merupakan alat komunikasi antara anggota masyarakat yang berupa sistem lambang bunyi yang bermakna, yang dihasilkan dari alat ucap manusia Di dalam kedudukannya sebagai bahasa nasional, Bahasa Indonesia berfungsi sebagai berikut:

a. Sebagai lambang kebanggaan nasional

b. Sebagai lambang jati diri atau identitas nasional

c. Sebagai alat pemersatu berbagai masyarakat yang berbeda latar belakang sosial, budaya, dan bahasanya

d. Sebagai alat perhubungan antarbudaya dan antar daerah. ${ }^{5}$

\section{METODE}

Penelitian ini menggunakan pendekatan kualitatif, sebab dalam melakukan tindakan kepada subjek penelitian, yang sangat diutamakan adalah mengungkap makna; yakni makna dan proses pembelajaran sebagai upaya meningkatkan motivasi, kegairahan dan prestasi belajar melalui tindakan dilakukan.

Jenis penelitian ini adalah Penelitian Tindakan Kelas (PTK), yaitu penelitian yang bertujuan untuk memberikan sumbangan nyata bagi peningkatan

\footnotetext{
${ }^{4}$ Henry Guntur tarigan. Membaca Sebagai Suatu Keterampilan Berbahasa. (Bandung: Angkasa. 2008). hlm: 7

${ }^{5}$ Mustakim, Membina Kemampuan Berbahasa, (Jakarta: PT Gramedia Putaka Utama, 1994 ). Hal.2
} 
profesionalisme guru, menyiapkan pengetahuan, pemahaman, dan wawasan tentang perilaku guru mengajar dan murid belajar.

\section{HASIL}

\section{Siklus Pertama}

\section{a. Perencanaan}

Pada perencanaaan tindakan pertama ini peneliti menerapkan metode CIRC dengan maksud membantu siswa yang memiliki kemampuan secara heterogen dalam memahami mata pelajaran bahasa indonesia pada aspek membaca yang difokuskan pada kegiatan membaca intensif dengan tanpa mengesampingkan cara-cara efektif dalam kegiatan membaca. Adapun perencanaan dalam siklus ini sebagai berikut:

1) Menyampaikan tujuan serta kompetensi pembelajaran yang akan dicapai oleh siswa

2) Penyususnan bahan bacaansiswa serta pembagian ringkasan materi tentang cara-cara penentuan pokok pikiran paragraf, cara meringkas bacaan, dan tips-tips membaca yang efektif

3) Membagisiswa dalam 7 kelompok yang terdiri dari 5 atau 6 dalam setiap kelompok akan mempelajari sebuah tema yang diberikanoleh guru termasuk mengumpulkan informasi yang berkaitan dengan tema tersebut

4) Membagi teks bacaan sesuai dengan tema yang diberikan kemudian meminta setiapa anggota kelompok untuk salingmembacakan teks bacaan tersebut secara bergantian dengan suara yang nyaring dan saling mengamati cara membaca masing-masing dari setiap anggota kelompok

5) Menugaskan setiap kelompok untuk mampu menentukan pokok pikiran paragraf serta meringkas teks bacaan

6) Secara bergantian ketua kelompok menunjuk anggotanya untuk mempresentasikan hasil kerja kelompoknya di depan kelas 
7) Mengadakan evaluasi secara bersama-sama tentang kegiatan pembelajaran yang sudah dilaksanakan

8) Penugasan kepada siswa yang bersifat individual yaitu pada setiap pertemuan diharuskan membawa bacaan anak-anak bukan dewasa seperti majalah bobo, cerita nusantara, pengetahuan umum dan lain sebagainya sesuai yang dimiliki oleh siswa.

\section{b. Pelaksanaan}

\section{Pertemuan Pertama}

\begin{tabular}{|c|c|c|}
\hline Kegiatan Guru & Kegiatan Siswa & $\begin{array}{l}\text { Alokasi } \\
\text { Waktu }\end{array}$ \\
\hline $\begin{array}{l}\text { Kegiatan Awal } \\
\text { Menanyakan kabar dan } \\
\text { kesiapan dalam belajar } \\
\text { Refresing fikiran (bermain } \\
\text { tepuk, bernyanyi, dsb) } \\
\text { Guru mengecek bahan } \\
\text { bacaan yang dibawa oleh } \\
\text { siswa } \\
\text { siswa untuk membacakan } \\
\text { sebuah bacaan di depan } \\
\text { kelas }\end{array}$ & $\begin{array}{l}\text { Siswa merespon } \\
\text { pertanyaan dari guru } \\
\text { Siswa mengikuti arahan } \\
\text { dari guru dengan } \\
\text { semangat } \\
\text { Siswa menunjukkan bahan } \\
\text { bacaan yang dibawa } \\
\text { Memperhatikan bacaan } \\
\text { yang dibaca temannya }\end{array}$ & 15 Menit \\
\hline
\end{tabular}




\begin{tabular}{|c|c|c|}
\hline $\begin{array}{l}\text { Kegiatan Inti } \\
\text { * Guru menjelaskan konsep } \\
\text { membaca intensif dengan } \\
\text { metode CIRC } \\
\text { * Guru membagikan sebuah } \\
\text { teks bacaan dengan tema } \\
\text { "sosial” kemudian } \\
\text { menjelaskan tugas yang } \\
\text { harus dikerjakan oleh } \\
\text { siswa secara kelompok } \\
\text { Membahas hasil kerja } \\
\text { kelompok secara } \\
\text { bersama-sama }\end{array}$ & $\begin{array}{l}\text { Siswa memperhatikan } \\
\text { keterangan guru dengan } \\
\text { seksama } \\
\text { Secara berkelompok } \\
\text { siswa identifikasi tema } \\
\text { Saling membacakan satu } \\
\text { sama lain, mencari kosa } \\
\text { kata sulit } \\
\text { Menetukan pokok pikran } \\
\text { paragraph dan membuat } \\
\text { ringkasan } \\
\text { Kelompok yang telah } \\
\text { selesai mempresentasikan } \\
\text { hasil kerjanya di depan } \\
\text { kelas }\end{array}$ & 40 menit \\
\hline $\begin{array}{ll}\text { Kegiatan Akhir } \\
* \text { Guru membacakan } \\
\text { kesimpulan dari kegiatan } \\
\text { belajar hari ini } \\
* \text { Pemberian semangat } \\
\text { motivasi belajar } \\
* \text { Penilaian hasil }\end{array}$ & $\begin{array}{l}\text { siswa merespon beberapa } \\
\text { pertanyaan dari guru }\end{array}$ & 15 menit \\
\hline
\end{tabular}

\section{Pertemuan kedua}

\begin{tabular}{|l|l|l|}
\hline Kegiatan Guru & Kegiatan Siswa & $\begin{array}{c}\text { Alokasi } \\
\text { Waktu }\end{array}$ \\
\hline
\end{tabular}




\begin{tabular}{|c|c|c|}
\hline $\begin{array}{l}\text { Kegiatan Awal } \\
\text { Berkunjung ke } \\
\text { perpustakaan sekolah } \\
\text { Menanyakan kabar dan } \\
\text { kesiapan dalam belajar } \\
\text { Refresing fikiran } \\
\text { (bermain tepuk, } \\
\text { bernyanyi, dsb) } \\
\text { Menanyakan pelajaran } \\
\text { yang lalu }\end{array}$ & $\begin{array}{l}\text { Siswa merespon } \\
\text { pertanyaan dari guru } \\
\text { Siswa mengikuti arahan } \\
\text { dari guru dengan } \\
\text { semangat } \\
\text { Siswa memperhatikan } \\
\text { dengan seksama }\end{array}$ & 15 Menit \\
\hline $\begin{array}{l}\text { Kegiatan Inti } \\
\text { Membuat kelompok } \\
\text { kelojar menjadi } 5 \\
\text { Menentukan tugas } \\
\text { kelompok awal mencari } \\
\text { bacaan dengan tema } \\
\text { bebas dan } \\
\text { menganalisisnya } \\
\text { Guru membagikan sebuah } \\
\text { teks bacaan kemudian } \\
\text { menjelaskan tugas yang } \\
\text { harus dikerjakan oleh } \\
\text { siswa secara individu } \\
\text { Pemberian PR membuat } \\
\text { karangan dengan tema } \\
\text { "Liburan" } \\
\text { Permaianan komunikata } \\
\text { untuk merefresh fikiran }\end{array}$ & $\begin{array}{l}\text { Secar berkelompok } \\
\text { mencari bacaan di } \\
\text { perpustakaan dengan tema } \\
\text { bebas, menganalisisnya, } \\
\text { dan membacakan di } \\
\text { depan } \\
\text { * Secara individu siswa } \\
\text { membaca bacaan } \\
\text { kemudian menentukan } \\
\text { pokok pikiran setiap } \\
\text { paragraf } \\
\text { Siswa mengikuti dengan } \\
\text { riang gembira }\end{array}$ & 40 menit \\
\hline
\end{tabular}




\begin{tabular}{|l|l|l|}
\hline \multicolumn{1}{|l|}{ siswa sekaligus melatih } & & \\
konsentrasi & Siswa merespon & \\
\hline Kegiatan Akhir & beberapa pertanyaan & \\
kesimpulan dari kegiatan & dari guru & \\
belajar hari ini & & \\
Pemberian semangat & & \\
motivasi belajar & & \\
\hline
\end{tabular}

\section{c. Pengamatan}

Dalam pengamatan peneliti pada siklus pertama ini penggunaan metode Cooperative Integrated Reading Composotion (CIRC)ini cukup baik. Ini dapat dilihat dari hasil yang ditunjukkan oleh para siswa, yaitu mereka cukup antusias dalam mengikuti kegiatan belajar mengajar. Hal ini dibuktikan dengan banyaknya siswa yang bertanya tentang isi bacaan yang telah mereka baca.

Selain itu, untuk melatih keberanian serta rasa pertanggung jawaban dari hasil kerja kelompok, siswa dilatih untuk presentasi hasil kerja kelompok secara bergantian. Meskipun presentasi di depan kelas belum berjalan secara maksimal, akan tetapi setidaknya siswa telah berani maju ke depan kelas untuk melaporkan hasil kerja kelompok mereka.

Metode CIRC membantu siswa untuk mampu mengelola isi sebuah bacaan menjadi beberapa sub-sub pokok bagian kemudian sub-sub pokok bagian yang telah ditemukan diceritakan kembali dengan menggunakan bahasa siswa sendiri atau yang lebih dikenal dengan aktivitas menceritakan kembali.

Terkait dengan perilaku yang kurang efektif yang digunakan siswa dalam membaca, seperti menggunakan jari untuk menunjuk kata, dan 
sebagainya masih tampak dilakukan siswa agak sulit untuk menghilangkan kebiasaan tersebut dalam aktivitas membaca.

\section{d. Refleksi}

Selanjutnya pada tahap ini peneliti beserta teman sejawat secara kolaboratif mengadakan diskusi untuk mengamati kegiatan pembelajaran yang telah berlangsung termasuk mengidentifikasi faktor-faktor hambatan dan kemudahan mengajar dengan menggunakan metode Cooperative Integrated Reading Composotion (CIRC) serta alternatif tindakan yang dilaksanakan selanjutnya.

Meskipun masih terdapat beberapa kesulitan yang dihadapi oleh siswa, akan tetapi penerapan metode CIRC pada siklus ini berjalan dengan cukup baik. Hal ini terlihat pada antusiasme yang ditunjukkan oleh peneliti sehingga mampu memahamkan siswa dalam mempelajarinya.

Dengan demikian metode CIRC memiliki peliang untuk mengembangkan pembelajaran mata pelajaran bahasa Indonesia khususnya pada aspek membaca, tergantung cara guru dalam menerapkan metode ini dalam kegiatan pembelajaran yang selanjutnya dapat menumbuhkan respon siswa dalam mengikuti setiap tahapan dalam penerapan metode CIRC.

\section{Siklus Kedua}

\section{a. Perencanaan}

Sebelum pelaksanaan pembelajaran dimulai terlebih dahulu peneliti menyusun rencana dari pelaksanaan tindakan II, sebagai berikut:

1) Menyampaikan tujuan serta kompetensi pembelajaran yang akan dicapai oleh siswa

2) Memfokuskan pembahasan pada memahami bacaan melalui membaca intensif yaitu membuat ringkasan bacaan

3) Penyususnan bahan bacaandengan berbagai tema 
4) Membagisiswa dalam 7 kelompok yang terdiri dari 5 atau 6 dalam setiap kelompok yang diketuai oleh salah satu siswa. Setiap kelompok akan mempelajari sebuah tema yang diberikanoleh guru termasuk mengumpulkan informasi yang berkaitan dengan tema tersebut

5) Membagikan majalah bobo kepada setiap kelompok untuk menunjang kegiatan pembelajaran kemudian mencari bacaan sesuai dengan tema yang telah ditentukan kepada setiap kelompok

6) Membaca bacaan dalam majalah bobo secara berkelompok, menanyakan kosa kata yang sulit kemudian presentasi perwakilan kelompok membahas garis besar isi yang terdapat dalam bacaan

7) Membagikan teks bacaan dengan tema "profesi” kemudian menjelaskan tugas kelompok yang saling membacakan satu sama lain, mengkoreksi mcara membaca satu sama lain, menentukan pokok pikiran, dan menyusun ringkasan dari teks bacaan tersebut secar berkelompok

8) Perwakilan kelompok presentasi di depan kelas membahas hasil ringkasan yang telah dikerjakan

9) Menyusun PR yang harus dikerjakan oleh siswa

10) Evaluasi bersama-sama terkait kegiatan pembelajaran yang telah dilaksanakan

11) Pelaksanaan post test

\section{b. Pelaksanaan}

\section{Pertemuan Pertama}

\begin{tabular}{|l|l|c|}
\hline \multicolumn{1}{|c|}{ Kegiatan Guru } & \multicolumn{1}{|c|}{ Kegiatan Siswa } & $\begin{array}{c}\text { Alokasi } \\
\text { Waktu }\end{array}$ \\
\hline $\begin{array}{l}\text { Kegiatan Awal } \\
\text { Menanyakan kabar dan } \\
\text { kesiapan dalam belajar } \\
\text { Refresing fikiran (bermain }\end{array}$ & $\begin{array}{l}\text { Siswa merespon } \\
\text { pertanyaan dari guru } \\
\text { Siswa mengikuti arahan }\end{array}$ & \\
\hline
\end{tabular}




\begin{tabular}{|c|c|c|}
\hline $\begin{array}{l}\text { tepuk, bernyanyi, dsb) } \\
\text { Menanyakan pelajaran } \\
\text { yang lalu }\end{array}$ & $\begin{array}{l}\text { dari guru dengan } \\
\text { semangat } \\
\text { Siswa memperhatikan } \\
\text { dengan seksama }\end{array}$ & \\
\hline $\begin{array}{l}\text { Kegiatan Inti } \\
\text { Menjelaskan tentang } \\
\text { pembuatan ringkasan } \\
\text { Pembentukan kelompok } \\
\text { (menjadi } 5 \text { kelompok) serta } \\
\text { pemberian tema pada setiap } \\
\text { kelompok } \\
\text { - Guru membagikan } \\
\text { sebuah majalah } \\
\text { Tugas : mencari bacaan } \\
\text { dalam majalah sesuai } \\
\text { dengan tema kelompok } \\
\text { kemudian mencari pokok } \\
\text { pikiran paragraf serta } \\
\text { membuat ringkasan (tugas } \\
\text { dilaksanakan dengan } \\
\text { kompetisi) } \\
\text { Membahas hasil kerja } \\
\text { kelompok secara bersama- } \\
\text { sama }\end{array}$ & $\begin{array}{l}\text { Memperhatikan dengan } \\
\text { seksama } \\
\text { Kelompok I } \\
\text { (Tumbuhan), } \\
\text { kelompok II } \\
\text { (Kesenian), Kelompok } \\
\text { III (Sejarah), } \\
\text { Kelompok IV } \\
\text { (Kesehatan), } \\
\text { Kelompok V } \\
\text { (Fenomena Alam) } \\
\text { Secara berkelompok } \\
\text { siswa melaksanakan } \\
\text { tugas dari guru } \\
\text { Siswa terpacu } \\
\text { semangatnya untuk } \\
\text { berkompetisi } \\
\text { Kelompok yang telah } \\
\text { selesai } \\
\text { mempresentasikan hasil } \\
\text { kerjanya di depan kelas }\end{array}$ & 40 menit \\
\hline Kegiatan Akhir & & \\
\hline
\end{tabular}




\begin{tabular}{|c|c|c|}
\hline $\begin{array}{l}\text { Guru membacakan } \\
\text { kesimpulan dari kegiatan } \\
\text { belajar hari ini } \\
\text { Pemberian semangat } \\
\text { motivasi belajar } \\
\text { Penilaian hasil }\end{array}$ & $\begin{array}{l}\text { Siswa merespon } \\
\text { beberapa pertanyaan } \\
\text { dari guru }\end{array}$ & 16 menit \\
\hline
\end{tabular}

\section{Pertemuan Pertama}

\begin{tabular}{|c|c|c|}
\hline Kegiatan Guru & Kegiatan Siswa & $\begin{array}{l}\text { Alokasi } \\
\text { Waktu }\end{array}$ \\
\hline $\begin{array}{l}\text { Kegiatan Awal } \\
\text { * Menanyakan kabar dan } \\
\text { kesiapan dalam belajar } \\
\text { * Refresing fikiran (bermain } \\
\text { tepuk, bernyanyi, dsb) } \\
\text { * Menanyakan pelajaran yang } \\
\text { lalu }\end{array}$ & $\begin{array}{l}\text { Siswa merespon } \\
\text { pertanyaan dari guru } \\
\text { Siswa mengikuti arahan } \\
\text { dari guru dengan } \\
\text { semangat } \\
\text { Siswa memperhatikan } \\
\text { dengan seksama }\end{array}$ & 15 Menit \\
\hline $\begin{array}{l}\text { Kegiatan Inti } \\
\text { Pelaksanaan post tes: } \\
\text { Tes lisan dan tes tulis }\end{array}$ & $\begin{array}{l}\text { Tes lisan: membaca } \\
\text { dengan suara nyaring, } \\
\text { menentukan pokok } \\
\text { pikiran, menceritakan } \\
\text { kembali } \\
\text { Tes tulis: menjawab } \\
\text { pertanyaan dari sebuah } \\
\text { bacaan }\end{array}$ & 40 menit \\
\hline $\begin{array}{l}\text { Kegiatan Akhir } \\
\text { Guru membacakan } \\
\text { kesimpulan dari kegiatan } \\
\text { belajar hari ini }\end{array}$ & $\begin{array}{l}\text { Siswa merespon } \\
\text { beberapa pertanyaan dari } \\
\text { guru }\end{array}$ & 17 menit \\
\hline
\end{tabular}




\begin{tabular}{|l|l|l|}
\hline Pemberian semangat & & \\
motivasi belajar & & \\
* Penilaian hasil & & \\
\hline
\end{tabular}

\section{c. Pengamatan}

Selama kegiatan pembelajaran berlangsung, peneliti bertindak sebagai guru sekaligus observer yang bertugas mencatat lembar pengamatan yang telah disusun pada pedoman observasi. Hasil pengamatan pada pelaksanaan siklus II siswa sudah mulai menunjukkan keantusiasannya dalam mengikuti kegiatan belajar mengajar. Dalam kegiatan inti guru mengajar dengan menggunakan metode CIRC yaitu dengan membagikan sebuah bacaan tidak terlalu panjang dengan tema "Profesi dan hobi" menganalisis tema yang disesuaikan dengan lingkungan sekitar.

\section{d. Refleksi}

Penggunaan metode CIRC yang berbasis strategi pembelajaran Cooperative Learning banyak menuntut peran aktif siswa baik dalam kerja kelompok maupun yang bersifat individu.

Untuk menindak lanjuti peningkatan keberhasilan siswa perlu diambil beberapa langkah agar kemampuan membaca siswa mampu ditingkatkan atau dipertahankan. Langkah-langkah tersebut antar lain:

1) Pemberian motivasi siswa untuk lebih gemar dalam membaca terutama dalam mengisi kekosongan waktu mereka

2) Peran serta guru dan lingkungan sekitar agar siswa tetap konsisten dalam belajar khususnya dalam kegiatan membaca termasuk penyediaan bacaan yang mampu menunjang pengetahuan siswa

3) Evaluasi terencana dan tersetruktur dalam mengukur tingkat keberhasilan siswa 


\section{PEMBAHASAN}

Pembelajaran kooperatif dengan metode CIRC adalah merupakan pembelajaran yang secara nyata mengajarkan siswa untuk mampu bekerja secara kooperatif atau bekerja sama dalam menyelesaikan dalam sebuah permasalahan. Hal ini dimaksudkan sebagai pembelajaran awal kepada siswa agar kelak dalam kehidupan yang sesungguhnya mampu hidup berdampingan dengan orang lain diatas beberapa perbedaan sehingga mampu menyikapi dengan positif perbedaan tersebut.

Penggunaan pembelajaran kooperatif dengan metode CIRC bertujuan untuk menumbuhkan semangat belajar siswa yang memungkinkan siswa dapat belajar dengan efektif dan efisien akan secara otomatis mempengaruhi hasil belajar siswa dan tentunya tercapainya tujuan-tujuan dari kegiatan pembelajaran, dalam hal ini khususnya mata pelajaran bahasa Indonesia aspek membaca pada kelas IV MI Mamba'ul Huda Ngabar Ponorogo.

Dalam pembelajaran dengan menggunakan metode CIRC sebanyak lebih $70 \%$ hasil belajar siswa mengalami peningkatan.selain dari hasil belajar yang mengalami peningkatan, kemampuan siswa untuk melakukan kegiatan membaca yang efektif juga mengalami peningkatan. Untuk mengetahui peningkatan kemampuan membaca yang telah di capai oleh siswa peneliti menggunakan penilaian yang bersifat lisan dan tulis, yaitu penilaian dari hasil belajar yang dicapai oleh siswa pada siklus I dan II dan penilaian dari hasil pengamatan peningkatan kemampuan membaca intensif dengan menggunakan beberapa indikator keberhasilan. Semua penilaian ini di lakukan dengan menggunkan metode wawancara, observasi serta dokumentasi pada kegiatan pembelajaran.

Selama pembelajaran berlangsung peneliti bertindak sebagai guru sekalaigus observer yang mengamati berlangsungnya kegiatan pembelajaran di kelas. Dalam melaksanakan kegiatan penelitian ini peneliti bekerja secara kolaboratif dengan teman sejawat dengan di bantu oleh guru pengampu mata pelajaran Bahasa Indonesia. 
Pada penelitian ini difokuskan pada aspek membaca intensif siswa pada mata pelajaran bahasa Indonesia dengan 3 indikator yaitu dengan membaca nyaring teks bacaan, menetukan pokok pikiran paragraf, dan membuat ringkasan bacaan.

Berdasarkan hasil tes pra tindakan yang telah dilakukan, maka dilakukanlah perencanaan serta pelaksanaan tindakan I untuk mengentaskan beberapa permasalahan pada kegiatan membaca siswa yang terjadi pada kegiatan tes pra tindakan.

Pada tindakan I, metode CIRC dikembangkan dengan yang sederhana pula. Selain itu guru juga membagikan rangkuman materi tentang penentuan pokok paragraf, cara membuat ringkasan, dan tips-tips membaca yang efektif yang disajikan dengan nuansa yang menarik agar siswa mampu memahmi materi dengan baik.

Sedangkan pada tindakan II pengembangan metode CIRC dikemas lebih menarik lagi yaitu dengan membagikan majalah anak-anak. Hal ini dilakukan untuk membantu siswa dalam memahami sebuah bacaan dan agar mampu menumbuhkan kegemaran mereka dalam membaca. Selain menggunakan media majalah anak-anak sebagai pelengkap penerepan metode CIRC di kelas, pengembangan kegiatan pembelajaran juga dengan menggunakan variasi yaitu dalm bentuk kompetisi atau semacam kuis untuk memacu semangat siswa dalam belajar.

Keberhasilan dari setiap kegiatan pembelajaran dengan menggunakan metode Cooperative Integrated Reading Composotion (CIRC) untuk meningkatkan kemampuan membaca siswa mata pelajaran Bahasa Indonesia dapat diamati dari beberapa bukti yang bersifat kuantitatif dan kualitatif.

Hasil belajar siswa selama ini telah memenuhi target yang telah ditentukan pada awal penelitian ini. Siswa diukur dengan 3 komponen penentu keberhasilan, yaitu lafal berkaitan dengan kata dan bunyi, tekanan kata yang berkaitan dengan informasi, pemenggalan kalimat karena berpengaruh pada makna secara keseluruhan. Hasil yang dipeoleh dari pengukuran kemampuan membaca intensif pada siklus I dapat diamati pada keterangan di atas. 
Sedangkan kesimpulan penilaian yang menunjukkan keberhasilan dalam meningkatkan kemahiran siswa pada kegiatan membaca ditunjukkan dengan beberapa kriteria, yaitu (1) kreatifitas dalam membaca, (2) menunjukkan minat untuk membaca, (3) membaca nyaring dengan lancar, (4) menulis dengan koheren, (5) menyimak dengan perhatian, (6) menyimpulkan gagasan dengan baik. Pelaksanaan penilaian ini dilakukan pada saat post test di akhir siklus II. Hasil penilaian ini menunjukkan ketuntasan dalam mengukur aktivitas siswa dalamm membaca.

Bukti-bukti secara kualitatif dapat dijelaskan dari hasilwawancara yang dilakukan peneliti dengan responden siswa dan hasil pengamatan di dalam kelas. Kebanyakan dari mereka mengungkapkan kesenangan dan antusiasme dalam mengikuti kegiatan pembelajaran dengan menggunakan metode Cooperative Integrated Reading Composotion (CIRC).

\section{PENUTUP}

Berdasarkan hasil penelitian dapat diambil kesimpulan bahwa:

1. Proses pelaksanaan penerapan model pembelajaran Cooperative Integrated Reading And Composition dilaksanakan sesuai dengan rencana yang telah disusun. Adapun penyusunan perencanaan difokuskan pada kemampuansiswa dalam menguasai indikator-indikator yang ditetapkan untuk mengukur keberhasilan membaca. Indikator-indikator tersebut terdiri dari kelancaran membaca, kejelasan suara dalam membaca, intonasi suara membaca, dan proseskerja sama antar anggota kelompok. Proses pelaksanaannya di bagimenjadi dua siklus. Pada siklus 1, secara singkat guru menjelaskan teknik membaca dengan benar. Setelah siswa cukup mengerti makaguru mulai mengajarkan proses pelaksanaan kerja kelompok dalampelaksanaan model pembelajaran CIRC. Agar siswa lebih faham, gurukemudian memberikan contoh dengan memberikan sebuah teks ceritakepada salah satu siswa, guru menjelaskan perintah dan meminta salahsatu siswa maju ke depan untuk mepresentasikan. Kegiatan selanjutnyadalah guru membagi siswa menjadi 
sembilan kelompok. Tiap-tiap kelompok diberi sebuah teks cerita untuk didiskusikan dengankelompoknya sendiri bagaimana cara mempresentasikan dan membacanya di depan kelas kelas dengan mengacu pada indikator yang ditetapkan.Guru memantau diskusi siswa. Pada siklus 2 guru berusaha menumbuhkankeberanian siswa dalam bekerja sama dengan teman sekelompoknya danmulai berusaha untuk menjalin eompakan dengan teman kelompoknya,meningkatkan kemampuan membaca dan menulis siswa denganmemberikan motivasi, memberikan contoh lebih detail, dan meningkatkan pengawasan.

2. Terdapat peningkatan kemampuan membaca dan menulis siswa secara bertahap ketika diterapkan model pembelajaran Cooperative Integrated Reading And Composition (CIRC). Untuk mengetahui proses peningkatan tersebut, guru melakukan evaluasi pada tiap siklusnya. Pada siklus 1,peningkatan yang dicapai siswa sangat kecil, hal itu karena pada siklus pertama banyak siswa yang masih merasa malu dan canggung dalam bekerja sama dengan teman kelompoknya dan masih merasa malu ketikapresentasi di hadapan guru dan teman-teman seelasnya. Dari siklus pertama, peneliti kemudian mengetahui bahwa permasalahan terbesaryang menghambat kemampuan membaca dan menulis siswa terletak padakurangnya kerjasama dengan anggota kelompoknya. Pada siklus 2, peneliti berupaya memunculkan aktifitas yang melibatkan siswa untuk bekerjasama dengan memberikan motivasi dan melakukan pembiasaan pada siswa untuk tampil berbicara dan berekspresi di depan. Dengan cara itu ternyata kemampuan membaca siswa pada siklus dua jauh lebih meningkat dibandingkan dengan siklus pertama, hasil evaluasi siswa sudah mencapai standar minimal ketuntasan yang ditetapkan. Dari paparan diatas dapat diambil kesimpulan bahwa model pembelajaran Cooperative Integrated reading And Composition(CIRC) mampu meningkatkan kemampuan membaca sehingga hasil yang diperoleh sudah memnuhi ketuntasan minimal. 


\section{DAFTAR PUSTAKA}

Amin Suyitno. 2005. Mengadopsi Pembelajaran CIRC dalam Meningkatkan Ketrampilan Siswa Menyelesaikan Soal Certia. Seminar Nasional F. MIPA UNNESA.

Anita Lie. 2007. Cooperative Learning Mempraktikkan Cooperative Learning di Ruang-Ruang Kelas. Jakarta: PT Grasindo.

Abdul majid. 2008. Perencanaan Pembelajaran Mengembangkan Standar Kompetensi Guru. Bandung: Rosda Karya.

Agus Suprijono. 2009. Cooperative Learning Teori dan Aplikasi Paikem. Yogyakarta:Pustaka Belajar.

A. S. Broto.1980. Pengajaran Bahasa Indonesia. Jakarta: Bulan Bintang.

Dr. Lexy J.Moleong, M.A.2002. Metodologi Penelitian Kualitatif. Bandung: Rosda Karya.

Dr. Mulyono Abdurrahman. 2003. Pendidikan Bagi Anak Berkesulitan Belajar, Jakarta: PT Asdi Mahasatya.

Imam syafi'ie.1990. Bahasa Indonesia Profesi. Malang: IKIP,

Mustakim, 1994. Membina Kemampuan Berbahasa.Jakarta: PT Gramedia Putaka Utama.

Puji Santoso, dkk. Cet.11.Ed.1. Materi dan Pembelajaran Bahasa Indonesia SD. Jakarta:Universitas Terbuka.

Suharsimi Arikunto.2002Prosedur Penelitian. Jakarta: Rineka Cipta edisi revisi V. Sukidin, dkk. 2002. Manajemen Penelitian Tindakan Kelas. (Surabaya: Insan Cendekia.

Solchan. 1996. Interaksi Belajar Mengajar Bahasa Indonesia SD. Malang: IKIP. Suryasubroto. 1997. Proses Belajar Mengajar di Sekolah. Jakarta: Rineka Cipta. 